\title{
Preliminary Assessment of Dampness in Walls of Residential Buildings in Four Climatic Zones in Ghana
}

\author{
Kofi Agyekum ${ }^{1}$, Joshua Ayarkwa ${ }^{1}$, Christian Koranteng $^{2}$ \& Emmanuel Adinyira ${ }^{1}$ \\ ${ }^{1}$ Department of Building Technology, Kwame Nkrumah University of Science and Technology, Kumasi, Ghana \\ ${ }^{2}$ Department of Architecture, Kwame Nkrumah University of Science and Technology, Kumasi, Ghana \\ Correspondence: Kofi Agyekum, Department of Building Technology, Kwame Nkrumah University of Science \\ and Technology, Kumasi, Ghana. Tel: 233-024-6761-879. E-mail: agyekum.kofi1@gmail.com
}

Received: June 17, 2013 Accepted: August 12, 2013 Online Published: August 19, 2013

doi:10.5539/jsd.v6n9p51 URL: http://dx.doi.org/10.5539/jsd.v6n9p51

\begin{abstract}
A questionnaire survey of inhabitants of 5,800 residential buildings was conducted in the Dry Equatorial, South Western Equatorial, Tropical Continental and the Wet Semi Equatorial climatic zones in Ghana to identify the most severe symptoms associated with dampness in the walls of residential buildings. Onsite building investigations were also conducted by trained assessors to identify the lead source of dampness in the walls of these residential buildings in Ghana. Data were analyzed using frequency and severity index. Majority of the houses surveyed were of lateritic materials and sandcrete block walls. The results showed that the most dominant symptoms in the walls of the residential buildings surveyed were hygroscopic salts, decayed skirting, dampness below $1.5 \mathrm{~m}$ and mold growth on walls up to $1 \mathrm{~m}$ high. These symptoms point to the presence of rising dampness as the lead source of dampness in the walls of these residential buildings. The results provide a platform for addressing the problem of rising dampness in buildings.
\end{abstract}

Keywords: buildings, climatic zones, dampness, rising damp, surface condensation, water penetration

\section{Introduction}

Buildings have an expected lifetime of 60 to over 100 years, during which they offer shelter from the weather to human beings, animals and properties. Weather and its variations cause degradation of building materials and structures (www.chalmers.se/.../building). When designing a sustainable building, it is important to take into consideration the location, natural shading, shelter (from storms, etc.) and structural materials (Cukierski, 1999). This is because certain parameters such as ambient air temperature and humidity, solar radiation, wind, precipitation and ground water cause different processes of deterioration in buildings. Serious environmental problems can also arise where existing buildings have other design problems. A common problem that can result from such conditions is moisture problems. Typical of these moisture problems is rising dampness, a type of dampness which occurs where ground water is conducted up through a masonry wall or a concrete floor slab. Moisture can damage shelving and increase humidity in a building (Cukierski, 1999). Dampness in buildings is one of the most widespread problems associated with both historic and modern types of buildings (Hetreed, 2008; Karoglou et al., 2007; Burkinshaw \& Parrett, 2004). Moisture in general causes damage to the exterior and interior walls of buildings, high heating energy consumption and uncomfortable indoor environment for occupants (Karouglou et al., 2007). The building envelope restoration suffering from moisture problems is one of the critical issues in sustainable refurbishment of buildings (Karouglou et al., 2007). The transfer of moisture in buildings is a very complex issue and has been a topical issue for decades. Moisture in buildings can cause deterioration of buildings by damaging brick/block work, cause decay and breaking up of mortar joints, fungal attack in timber and corrosion in iron and steel as well as stained wall surfaces internally and externally (Trotman et al., 2004). Damp surfaces encourage the formation of mold, and the spread of mold and mites in conditions of high relative humidity is associated with ill health (World Health Organization, WHO, 2009). Damp conditions also typically affect the mental health of dwelling occupants, causing depression and anxiety, particularly where there is damage to decoration from mold or damp staining (Nicol, 2006). As the most frequently reported cause of building deterioration, dampness in all its forms has assumed an alarming proportion and countries like the United Kingdom, United States of America, Australia, Denmark, Canada, Japan, Estonia, Iceland, Norway, Sweden, Taiwan, etc. have recorded the enormity of the problem (WHO, 2009; 
Mudarri \& Fisk, 2007; Gunnbjornsdotirr et al., 2006). The problem is also pronounced in Ghana as studies conducted on the health of patients have shown that most respiratory diseases are caused by this problem (Asamoah et al., 2012). This study sought to identify the lead source of dampness in the walls of residential buildings in Ghana.

\section{Literature Review}

\subsection{Housing Characteristics in Ghana}

The official data of the Ghana Statistical Service, GSS, on the distribution of housing in Ghana reported that there were $2,181,975$ houses countrywide, even though a total of 3,877,418 housing units or places of abode were also recorded. This implies about 1,695,443 houses or places of abode inhabited by a number of households are not conventional houses. This follows variations in definitions of a dwelling place and a house by the GSS (Bank of Ghana, BOG, 2007; GSS, 2005).



Figure 1. Distribution of housing in Ghana (GSS, 2005)

A dwelling unit is defined as a specific area or space occupied by a particular household and therefore need not necessarily be the same as a house or building of which the dwelling unit may be part (BOG, 2007). A house or building is defined as a structurally separate or independent place of abode such that a person or group of persons can isolate themselves from the hazards of climate such as storms and the sun (BOG, 2007; GSS, 2005).

In the 2000 population census, the GSS classified occupied dwellings into 10 categories as follows: rooms in a compound; separate house (detached house); semi-detached house; several huts/buildings; improvised house (kiosk/container); living quarters attached to a shop; camps or tents; hotel or hostel; flat or apartment and others. Of these, compound houses accounted for 45 per cent and emerged as the most common dwelling unit in both urban and rural areas. Separate or detached houses $(24.1 \%)$ were found to be the second most common dwelling type in all regions (ranging from 15.9\% - 27.2\%) except the Volta Region (44.7\%) where this type is predominant. Semi-detached house $(15.2 \%)$ is the third most common type in all regions and in rural $(15.6 \%)$ and urban (14.8\%) localities. Flats or apartments are ranked fourth in the country (4.2\%) and in urban localities (7.2\%). Improvised houses (kiosk/container) and living quarters attached to a shop' were found mainly in urban localities of the Greater Accra and Ashanti Regions due to rural urban migration. In Greater Accra, for example, these improvised houses (kiosks and containers) are used for both commercial and residential purposes (Bank of Ghana, 2007; GSS, 2005).

The type of building material used by individuals and institutions depend on cost, availability and people's ability to pay for these materials. The two main materials for the construction of the outer walls of a house in Ghana are mud brick/earth and cement/concrete, which together account for 89.1 per cent of wall materials of dwelling units (GSS, 2005). The earth/mud brick constitutes 50.0 per cent while concrete/cement is used in 39.1 per cent of the cases. The use of timber in building main walls of houses account for 4.0 percent, which is probably because of high cost, fire hazard and the follow up on maintenance costs (GSS, 2005).

The use of these materials as walling materials have seen many problems over the years including dampness, which results from moisture finding its way into the walls of the buildings (coralghana.com). This study seeks to identify the most dominant type of dampness in the walls of residential buildings in Ghana. 


\subsection{Dampness in Buildings}

Dampness can be defined as water penetration through the walls and certain elements of a building (Halim et al., 2012). Dampness can also be defined as an excessive quantity of moisture contained in building materials and components which causes adverse movements or deterioration and results in unacceptable internal environmental conditions (Briffet, 1994). Burkinshaw and Parrett (2004) defined dampness as the amount of moisture content present in a material and can be classified as capillary moisture content, equilibrium moisture content, hygroscopic moisture content, total moisture content and potential moisture content. Dampness is the most frequent and main problem in buildings and contributes more than $50 \%$ of all known building failures (Halim et al., 2012; Trotman, 2004). According to Hollis (2000), dampness is inextricably linked to most building deterioration. A source of water close to a building will also be one of the problems associated with dampness. These problems include symptoms such as dirty spots on the building, biological plants like the growth of fungi, mosses and creeping plants, paint flaking, blistering etc. (Halim et al., 2012). In order to successfully diagnose and make appropriate recommendations for remedial actions, one should understand dampness and its impact on buildings.

The ultimate objective of any dampness study is to identify the lead source of moisture in order to recommend actions to remedy the problem (Halim et al., 2012). According to Hollis (2000), sources of dampness can be classified as rising dampness, penetrating dampness, condensation and pipe leakages. According to Burkinshaw and Parrett (2004), dampness can be classified as air moisture condensation, penetrating dampness, internal plumbing leaks, below ground moisture or building specific sources.

Rising dampness occurs as a result of capillary suction of moisture from the ground into porous masonry building materials such as stone, brick, blocks, earth and mortar (Halim \& Halim, 2010; Ahmed \& Rahman, 2010; Riley \& Cotgrave, 2005; Trotman et al., 2004; New South Wales Heritage Office, NSWHO, 2005). The moisture evaporates from either face of the wall (inside or outside), allowing more to be drawn from below. The height to which the moisture will rise is determined by the evaporation rate and the nature of the wall (Halim \& Halim, 2010; Ahmed \& Rahman, 2010; Trotman et al., 2004; Riley \& Cotgrave, 2005; NSWHO, 2005). The normal limit for rising dampness ranges from $0.5 \mathrm{~m}$ to $1.5 \mathrm{~m}$ above ground level (Halim \& Halim, 2010; Ahmed \& Rahman, 2010; Trotman et al., 2004; Riley \& Cotgrave, 2005; NSWHO, 2005). Rising dampness may show as a high-tide-like stain on wall paper and other interior finishes, and, when it is severe, as blistering of paint and loss of plaster. Damp walls encourage the growth of mold which in conjunction with high humidity, can lead to health problems to occupants (Halim \& Halim, 2010; Ahmed \& Rahman, 2010; Trotman et al., 2004; Riley \& Cotgrave, 2005; NSWHO, 2005).

Water penetration through a building enclosure depends on the simultaneous occurrence of three things: the presence of water; an opening through which water can enter and a physical force to move the water (Beall, 2000). Water can be present as rain, melting snow and soil moisture. Several forces such as gravity, air currents, capillary suction, surface tension, kinetic energy, air pressure and hydrostatic pressure influence the penetration of water into buildings (Beall, 2000). Drips from air conditioning or hot water system overflows, rain water, pipe leakages, water from horizontal directions, etc. can also cause penetration dampness in buildings (NSWHO, 2005). These sources tend to produce small, localized patches of dampness and decay, whereas rising dampness may affect the base of a whole building (NSWHO, 2005).

According to Curtis (2007), dampness resulting from condensation occurs where water in the air inside a building condenses on a cooler surface. This is usually indicative of cold spots in the building, sometimes called cold bridges (Curtis, 2007). It can also occur where there is poor ventilation or where short intense heating cycles do not allow the walls to fully warm up (Curtis, 2007). This situation allows the heated air to hold more water, which condenses when the temperature drops (Curtis, 2007). Excessive condensation frequently results in severe mould growth which can in turn create health hazards. Condensation is one of the most common forms of dampness in residential buildings, mainly caused by warm moist air formed from cooking, washing, bathing or even by just breathing, condensing onto colder surfaces in the homes (Burns, 2010). Damp patches can appear on plaster walls in odd places, particularly on outside walls, often appearing and disappearing on a regular basis (Burns, 2010). Condensation is mostly accompanied by mold which is black in colour but can virtually be of any colour and is very common on walls and ceiling, underneath bay windows, etc. (Burns, 2010). According to the British Research Establishment (BRE), $80-85 \%$ of dampness problems in the United Kingdom arise due to condensation or manmade moisture (Ryan, 2002).

There are many visual signs to look out for when diagnosing any damp situation (South Northamptonshire Council, SNC, 2012). In Denmark, rising dampness in the walls of buildings is associated with symptoms such 
as salt efflorescence, deterioration of rendering and plastering mortar, deterioration of wooden parts of buildings, etc. Condensation is associated with mold growth, usually on top of walls and ceilings (Burns, 2010). Rising dampness may show as a high-tide-like stain on wall paper and other interior finishes, and, when it is severe, as blistering of paint and loss of plaster (Halim \& Halim, 2010; Ahmed \& Rahman, 2010; Burns, 2010; Curtis, 2007; Trotman et al., 2004; Riley \& Cotgrave, 2005; NSWHO, 2005). Mold growth may also be associated with rising and penetration dampness in buildings (Burns, 2010). The 1991 House Condition Survey found that 10.4million homes were affected by mold growth (Ryan, 2002; Wheeler \& Critchley, 1998) and the Northern Ireland House Condition Survey in 1996 also found that 16\% of homes experienced some form of mold growth (Ryan, 2002).

\subsubsection{Diagnosing Dampness}

Dealing effectively with the problem of dampness requires the adoption of an organized system of investigative procedures to confirm all the sources of dampness and to ensure that the recommended remedial works are appropriate (Halim et al., 2012). Such a system must commence with identifying and recognizing symptoms or signs of dampness (Halim et al., 2012). A professional who undertakes any form of building inspections should be aware of information already available (Carillion, 2001). The selection of an effective remedy for any form of dampness must start with a correct diagnosis of the cause (Carillion, 2001). There are four major stages to any dampness investigation. These are visual inspection, investigations using moisture meters/ non-destructive tests, a more detailed investigation/destructive tests and homing in on the problem/assessment study (Halim et al., 2012; Burkinshaw \& Parrett, 2004). This study is a preliminary investigation and based on stage 1, thus the visual inspection stage. This procedure requires a surveyor to inspect the defect closely and it is the first of the four stages involved in any dampness investigation. This stage may be subjective and based on experience and skill of the personnel involved (Halim et al., 2012). The identification of a dampness problem is dependent on the symptom of defect i.e. staining of water, cracking, rotten timber, decay, blisters, etc. (Halim et al., 2012; Burkinshaw \& Parrett, 2004). The diagnosis requires knowledge of the behavior of relevant building materials, construction knowledge and knowledge on the use (past, present and future) of the building. The surveyor needs to record the defect by description, photograph or sketch drawings, etc. (Halim et al., 2012; Burkinshaw \& Parrett, 2004).

\section{Research Methodology}

The study was conducted through field surveys by trained assessors to identify the most severe symptoms and the lead source of dampness in walls of residential buildings in Ghana. The main instruments used for data collection were structured questionnaire surveys made up of closed-ended questions and a checklist for on-site building investigations by trained assessors. The questionnaires were administered to building occupants of residential buildings in the four climatic regions of Ghana. Four main climatic regions are distinguished in Ghana; South-Western Equatorial (SWE), Dry Equatorial (DE), Wet Semi-Equatorial (WSE) and Tropical Continental or Savanna (TC) (Abass, 2009). The principal characteristics of each climatic region are based on rainfall, temperature, humidity, etc (Abass, 2009). The South Western Equatorial Climatic zone is the wettest climatic region in Ghana. The rainfall regime is the double maximum type. Mean annual rainfall is above $1,900 \mathrm{~mm}$ and on the average, no month has less than $25 \mathrm{~mm}$ of rain. The highest mean monthly temperature of about $30^{\circ} \mathrm{C}$ occurs between March and April and the lowest of about $26^{\circ} \mathrm{C}$ in August. A typical station for this climatic region is Axim (Abass, 2009). The Dry Equatorial climatic zone has two rainfall maxima: but the dry seasons are more marked and the mean annual rainfall is considerably less- between 740 and $890 \mathrm{~mm}$. This region is the driest in Ghana. Temperatures are almost the same as in the south-west equatorial climatic region, and average monthly relative humidity is higher in the rainy seasons than during the rest of the year. A typical station for this climatic region is Accra. Cape Coast, Sekondi Takoradi and Ho also fall within this climatic region (Abass, 2009). The Wet Semi Equatorial Climatic zone has two rainfall maxima, but the mean annual rainfall is between 1,250 and $2,000 \mathrm{~mm}$. Some of the wetter areas include the Akwapim-Togo ranges and the Southern Voltarian plateau where annual rainfall sometimes exceeds the second rainy season (from September to October). A typical station for this climatic region is Kumasi. Other towns include Sunyani, Koforidua and Enchi (Abass, 2009). The Tropical Continental climate has a single rainy season from May to October followed by a prolonged dry season. The mean annual rainfall is about 1,000 to $1,150 \mathrm{~mm}$. Mean monthly temperatures vary from $36^{\circ} \mathrm{C}$ in March to about $27^{\circ} \mathrm{C}$ in August. A typical station for this climate is Zuarungu. Among the other towns in this zone are Navrongo, Bawku, Wa, Tamale, Salaga and Yendi (Abass, 2009).

The questionnaires distributed to the building occupants sought information about the type of buildings, the materials used to construct the walls and symptoms associated with dampness in walls identified from literature (Ahmed \& Rahman, 2010; Burns, 2010; Trotman, 2004; Nicol, 2006; Riley \& Cotgrave, 2005; CWC, 2000). 
The respondents were asked to rank the level of severity of the symptoms associated with dampness in walls on the Likert scale of $1-5$, where $1=$ Not severe, $2=$ Less severe, $3=$ Neither Severe nor very severe, $4=$ Severe and $5=$ Very severe. Respondents who were made up of heads of households and tenants were assisted by technical experts in ranking the severity of the symptoms, hence, though expressing a lay person's opinion on the symptoms, the results on the severity of symptoms could be said to be varied. The checklist in Table 1, containing symptoms of dampness collected from the literature and modified to suit conditions in Ghana was pre-tested by trained assessors using 50 buildings and used for the study (Burns, 2010; Safeguard Europe Limited, SEL, 2007). In order to identify the most dominant type (lead source) of dampness, the trained assessors used the checklist in Table 1.

Table 1. Symptoms associated with rising damp, surface condensation and water penetration

\begin{tabular}{|c|c|c|c|}
\hline SYMPTOMS & RISING DAMPNESS & $\begin{array}{c}\text { SURFACE } \\
\text { CONDENSATION }\end{array}$ & $\begin{array}{c}\text { WATER } \\
\text { PENETRATION }\end{array}$ \\
\hline $\begin{array}{l}\text { Water droplets/free flowing water } \\
\text { on surface }\end{array}$ & Absent & $\begin{array}{l}\text { Yes, but depends on } \\
\text { surface conditions }\end{array}$ & $\begin{array}{l}\text { Present (depends on } \\
\text { severity) }\end{array}$ \\
\hline Hygroscopic salts & Present & Absent & Absent \\
\hline Moisture in skirting & $\begin{array}{l}\text { Present (High if in direct } \\
\text { contact with wall) }\end{array}$ & Low & $\begin{array}{l}\text { Depends on position of } \\
\text { water ingress }\end{array}$ \\
\hline Moisture above $1.5 \mathrm{~m}$ & Sometimes & Depends on conditions & $\begin{array}{c}\text { Present (depends on } \\
\text { position of water ingress) }\end{array}$ \\
\hline Dampness below $1.5 \mathrm{~m}$ & Present & Absent & Absent \\
\hline Mold on walls about $1 \mathrm{~m}$ high & Present & Absent & Absent \\
\hline Mold on ceilings and top of walls & Absent & $\begin{array}{l}\text { Present (depends on } \\
\text { severity) }\end{array}$ & $\begin{array}{l}\text { Present (depends on } \\
\text { surface conditions) }\end{array}$ \\
\hline
\end{tabular}

Houses located in the major towns in the four main climatic regions were considered in the survey. According to the Ghana Statistical Service (2005), the number of buildings located in each town are as follows: Sekondi-Takoradi in the Western region (with 24,817 buildings), Axim in the Western region (with 2,694 buildings), Cape Coast in the Central region (with 6,847 buildings), Accra in the Greater Accra region (with 131,355 buildings), Ho in the Volta Region (with 6,853 buildings), Koforidua in the Eastern Region (with 7,318 buildings), Kumasi in the Ashanti Region (with 67,434 buildings), Sunyani in the Brong Ahafo Region (with 5,611 buildings), Tamale in the Northern Region (with 15, 873 buildings), Bolgatanga in the Upper East Region (with 3,932 buildings) and Wa in the Upper West Region (with 5,539 buildings). A sample size of 5,800 buildings which showed symptoms of dampness were selected from the total population of 278,273 buildings in the selected locations for the entire survey using the formula

$$
\text { (Yamane, 1967) }: n=N / 1+N(e)^{2}
$$

Where $\mathrm{N}=$ the total population size; $\mathrm{e}=$ the standard error of sampling distribution assumed to be 0.013 and $\mathrm{n}$ is the sample size. Proportionate or quota sampling technique was used to select the sample size for each location as follows: Sekondi-Takoradi (517 buildings), Axim (56 buildings), Cape Coast (143 buildings), Accra (2738 buildings), Ho (143 buildings), Koforidua (153 buildings), Kumasi (1,406 buildings) Sunyani (117 buildings), Tamale (330 buildings), Bolgatanga (82 buildings) and Wa (115 buildings). The convenience purposive sampling approach was then used to select the residential buildings within each location (representing a cross section of buildings in the four climatic regions of Ghana). In all, $1 \%$ of the buildings $(56$ out of 5,800$)$ was selected from the South Western Equatorial, 61\% (3,541 out of 5,800) were selected from the Dry Equatorial, $29 \%(1,689$ out of 5,800) were selected from the Wet Semi Equatorial and 9\% $(545$ out of 5,800) were selected from the Tropical Continental Climatic Zones respectively.

A quantitative approach to data analysis was employed. Statistical Package for Social Scientists Version 16 (SPSS V 16) was used to analyze the data by means of frequencies and severity index. The severity index analysis (Idrus, 2011) uses weighted percentage scores to compare the relative importance of the criteria under study. The frequency analysis was first carried out to determine the frequency of responses which were then used to calculate severity indices (Idrus et al., 2011): Severity Index 


$$
(\mathrm{SI})=\frac{\left[\sum a i . x i\right]}{\left[5 \sum x i\right]} \times 100 \%
$$

$X i=$ Variable expressing the frequency of the response for $i ; i=1,2,3,4$ and $5 ; \mathrm{X} 1=$ Frequency of the 'not severe' response and corresponding to $\mathrm{a} 1=1 ; \mathrm{X} 2=$ Frequency of the 'less severe' response and corresponding to $\mathrm{a} 2=2 ; \mathrm{X} 3=$ Frequency of the 'neither severe nor very severe' response and corresponding to $\mathrm{a} 3=3$; $\mathrm{X} 4=$ Frequency of the 'severe' response and corresponding to $\mathrm{a} 4=4$; X $5=$ Frequency of the 'very severe' response and corresponding to a5 $=5$.

\section{Results and Discussions}

\subsection{Characteristics of Buildings}

Table 2 shows the characteristics of the buildings surveyed in the four climatic zones in Ghana. The results show that $71 \%$ of the respondents interviewed in the South Western Equatorial Zone, $77 \%$ of the respondents interviewed in the Dry Equatorial Climatic Zone and 56\% of the respondents in the Wet Semi Equatorial Climate Zone live in detached buildings. In the Tropical Continental Climatic Zone, $62 \%$ of the respondents live in compound houses. This confirms that compound and detached buildings are the major types of buildings occupied by people in Ghana (GSS, 2005).

Table 2. Characteristics of buildings surveyed

\begin{tabular}{|c|c|c|c|c|c|c|c|c|}
\hline \multirow[b]{2}{*}{$\begin{array}{l}\text { Characteristics } \\
\text { dwellings }\end{array}$} & \multicolumn{2}{|c|}{$\begin{array}{c}\text { South Western } \\
\text { Equatorial }\end{array}$} & \multicolumn{2}{|c|}{ Dry Equatorial } & \multicolumn{2}{|c|}{ Wet Semi Equatorial } & \multicolumn{2}{|c|}{ Tropical Continental } \\
\hline & Frequency & Percentage & Frequency & Percentage & Frequency & Percentage & Frequency & Percentage \\
\hline \multicolumn{9}{|l|}{ Type of dwelling } \\
\hline Detached/separate & 40 & $71 \%$ & 2,744 & $77 \%$ & 946 & $56 \%$ & 136 & $25 \%$ \\
\hline Semi detached & 4 & $7 \%$ & 485 & $14 \%$ & 203 & $12 \%$ & 49 & $9 \%$ \\
\hline Block flat/Apartment & 2 & $4 \%$ & 208 & $6 \%$ & 473 & $28 \%$ & 22 & $4 \%$ \\
\hline Compound & 10 & $18 \%$ & 104 & $3 \%$ & 67 & $4 \%$ & 338 & $62 \%$ \\
\hline TOTAL & 56 & $100 \%$ & 3,541 & $100 \%$ & 1,689 & $100 \%$ & 545 & $100 \%$ \\
\hline \multicolumn{9}{|l|}{ Walling material } \\
\hline Concrete & 0 & $0 \%$ & 104 & $3 \%$ & 51 & $3 \%$ & 0 & $0 \%$ \\
\hline Earth & 6 & $11 \%$ & 104 & $3 \%$ & 118 & $7 \%$ & 360 & $66 \%$ \\
\hline Burnt bricks & 0 & $0 \%$ & 0 & $0 \%$ & 118 & $7 \%$ & 82 & $15 \%$ \\
\hline Sandcrete blocks & 50 & $89 \%$ & 3,333 & $94 \%$ & 1,402 & $83 \%$ & 104 & $19 \%$ \\
\hline TOTAL & 56 & $100 \%$ & 3,541 & $100 \%$ & 1,689 & $100 \%$ & 545 & $100 \%$ \\
\hline
\end{tabular}

The results (Table 2) further show that in the South Western Equatorial climatic zone, $89 \%$ of the walls of buildings were constructed with sandcrete blocks and only $11 \%$ were constructed with earth. In the Dry Equatorial climatic zone, $94 \%$ of the walls of buildings surveyed were constructed with sandcrete blocks, $3 \%$ were constructed with earth and 3\% were constructed with concrete. In the Wet Semi Equatorial climatic zone, the walls of buildings were constructed with concrete, earth, burnt bricks and sandcrete blocks. However, sandcrete blocks gained more usage as $83 \%$ of the outer walls were constructed with sandcrete blocks in this zone. In the Tropical continental climatic zone, $66 \%$ of the walls of buildings were constructed with earth. The results show that the outer walls of buildings surveyed in the four climatic zones of Ghana were mostly constructed with sandcrete blocks and earth, though concrete and burnt bricks were used in minor cases. This confirms that the outer walls of buildings in Ghana are constructed of sandcrete blocks, earth, concrete and burnt bricks (GSS, 2005).

\subsection{Severity of Symptoms Associated with Dampness}

The results (Table 3) show that 'mold growth (on cold surfaces, windows, etc)' is the most severe symptom of dampness (with SI of 90\%) associated with walls in the South Western Equatorial climatic zone and therefore ranked first on the list of symptoms. In the Tropical Continental climatic zone, 'dampness at the base of walls up to $1.5 \mathrm{~m}$ in horizontal band is ranked first on the list (with SI of $84 \%$ ) as the most severe symptom associated 
with dampness in the walls of buildings. Stains, especially in horizontal band are ranked first (with SI of 97\%) on the list of symptoms as the most severe symptom associated with dampness in the walls of buildings in the Wet Semi Equatorial climatic zone. In the Dry Equatorial climatic zone, 'surface efflorescence just above skirting/floor' is the most severe symptom (with SI of $89 \%$ ) and therefore ranked first on the list of symptoms associated with dampness.

Table 3. Severity of symptoms associated with dampness in buildings

\begin{tabular}{|c|c|c|c|c|c|c|c|c|}
\hline \multirow[b]{2}{*}{ Symptom } & \multicolumn{2}{|c|}{$\begin{array}{l}\text { South Western } \\
\text { Equatorial } \\
\text { (SEW) }\end{array}$} & \multicolumn{2}{|c|}{$\begin{array}{c}\text { Tropical } \\
\text { Continental } \\
\text { (TC) }\end{array}$} & \multicolumn{2}{|c|}{$\begin{array}{c}\text { Wet Semi } \\
\text { Equatorial } \\
\text { (WSE) }\end{array}$} & \multicolumn{2}{|c|}{ Dry Equatorial (DE) } \\
\hline & S.I. & Rank & S.I. & Rank & S.I & Rank & S.I. & Rank \\
\hline Decayed skirting & $33 \%$ & 9 th & $40 \%$ & 9 th & $28 \%$ & 10th & $44 \%$ & $10 t h$ \\
\hline Dampness around edges of solid floor & $32 \%$ & 10th & $77 \%$ & 6 th & $43 \%$ & 8 th & $70 \%$ & 6 th \\
\hline $\begin{array}{l}\text { Surface efflorescence just above } \\
\text { skirting/floor }\end{array}$ & $88 \%$ & $2 n d$ & $83 \%$ & $2 n d$ & $84 \%$ & $4 t h$ & $89 \%$ & lst \\
\hline $\begin{array}{l}\text { Dampness at the base of walls up to } 1.5 \mathrm{~m} \\
\text { in horizontal band }\end{array}$ & $86 \%$ & $3 r d$ & $84 \%$ & $1 s t$ & $89 \%$ & $2 n d$ & $86 \%$ & $3 r d$ \\
\hline Stains, especially in horizontal band & $86 \%$ & $3 r d$ & $79 \%$ & 5 th & $97 \%$ & $1 s t$ & $87 \%$ & $2 n d$ \\
\hline Mold growth & $90 \%$ & $1 s t$ & $81 \%$ & 4 th & $85 \%$ & $3 r d$ & $85 \%$ & $4 t h$ \\
\hline Free surface water, water run marks, etc. & $85 \%$ & 5 th & $83 \%$ & 2nd & $84 \%$ & $4 t h$ & $77 \%$ & 5 th \\
\hline Blistering and flaking of paint & $49 \%$ & 6 th & $54 \%$ & $7 t h$ & $40 \%$ & 9 th & $53 \%$ & 8 th \\
\hline Softening and deterioration of plaster & $38 \%$ & $7 t h$ & $53 \%$ & 8 th & $60 \%$ & 7 th & $61 \%$ & $7 t h$ \\
\hline Dampness on first floor and above & $34 \%$ & $8 t h$ & $28 \%$ & 10th & $61 \%$ & 6 th & $52 \%$ & 9 th \\
\hline
\end{tabular}

The results show that each climatic zone has a unique symptom associated with walls of buildings. This is a situation likely to be caused by the differences in climatic conditions of each zone. For instance, mold growth highly associated with buildings in the South Western Equatorial climatic zone does not require the presence of standing water: it can occur when high relative humidity or the hygroscopic properties of building surfaces allow sufficient moisture to accumulate (www.epa.gov/laq/largebldgs/). Also, studies have shown that moisture levels within buildings are often higher than outdoors. The high indoor moisture levels result from the generation of warm moist air by domestic activities such as cooking, bathing/showering, clothes drying, high occupancy, etc. These are all factors which contribute to the raising of the indoor relative humidity. An increase in the Relative humidity increases the dew point temperature for the same air temperature. This will increase the risk of condensation should the water vapour come into contact with a surface below dew point (Australian Building Codes Board, ABCB, 2011). In the South Western Equatorial climatic zone, average monthly relative humidity levels (based on figures recorded each day at 12 noon) are highest as compared to the other climatic zones and range between $75-80 \%$, a possible reason for walls being affected by mold growth in this zone. Tropical climates typically have high outdoor temperatures combined with high relative humidity and this result in high outdoor vapour pressure. This creates a slight inward vapour flow. For an air-conditioned building in a Tropical climate the indoor vapour pressure is reduced as both the indoor temperature and humidity is reduced. This results in a large vapour pressure difference, creating a much greater inward vapour flow (ABCB, 2011). Majority of the buildings which were surveyed in the South Western Equatorial Climatic zone had no air conditioning systems but had high occupancy rates, hence moisture generation activities was greater. It was realized from the study that temperature differences between rooms and between the interior and exterior had little contribution to the problem of condensation which created the mould growth in this climatic zone.

Cyclic wetting and drying brought about by seasonal changes is an important driver of salt attack or efflorescence in walls of buildings (Young, 2008). Changes in the relative humidity of a location can cause efflorescence to occur (Young, 2008). Surface efflorescence in walls is caused by rapid evaporation of water from wall surfaces leaving behind salt crystals (Young, 2008). As the Dry Equatorial Climatic zone is characterized by drying, there is that tendency of rapid evaporation of moisture from walls of buildings in this zone which could lead to the formation of salt bands on the surfaces of walls. One of the reasons why the surface efflorescence is the most severe symptom of dampness associated with buildings in this climatic zone. Though surface efflorescence was pronounced in buildings in the Dry Equatorial Climatic zone, buildings located within 
the other climatic zones also showed this symptom. According to ABCB (2011), many building materials are manufactured with salts and chemical preservatives and remain relatively inert when dry. During construction in coastal environments building materials may also become coated with salt before the building is enclosed. In a high humidity environment, materials can release these salts and chemicals with damaging consequences for the occupants, contents and furnishings of the building and other adjacent materials such as fixings that may corrode when exposed to such salts and chemicals (ABCB, 2011).

The results from this study confirm that mold growth, stains, especially in horizontal band, dampness at the base of walls up to $1.5 \mathrm{~m}$ in horizontal band and surface efflorescence are the most severe symptoms associated with dampness in walls of residential buildings in Ghana. This finding corroborates that of literature, which identified mold growth, surface efflorescence, water run marks, blistering of paints, etc. to be symptoms associated with dampness in the walls of buildings (Hetreed, 2008; Burkinshaw \& Parrett, 2004; Trotman et al., 2004; Mbachu, 1999).

\subsection{Identification of the Most Dominant Type of Dampness in Buildings}

Table 4 presents symptoms associated with rising dampness, condensation and water penetration identified from the survey. This part of the study is based on the results obtained from the checklist (Table 1) used by the trained assessors for the onsite building investigation. For the purpose of this study, where two sources of dampness exhibited the same symptoms, the source which showed the most severe symptom was considered significant.

Table 4. Dominant types (lead sources) of dampness in buildings based on symptoms

\begin{tabular}{|c|c|c|c|c|c|c|c|c|c|c|c|c|}
\hline \multirow{3}{*}{ Type of } & \multicolumn{3}{|c|}{$\begin{array}{c}\text { WET SEMIEQUATORIAL (KUMASI, } \\
\text { KOFORIDUA AND SUNYANI) }\end{array}$} & \multicolumn{3}{|c|}{$\begin{array}{l}\text { TROPICAL CONTINENTAL (TAMALE, } \\
\text { WA, BOLGATANGA) }\end{array}$} & \multicolumn{3}{|c|}{$\begin{array}{l}\text { DRY EQUATORIAL (ACCRA, } \\
\text { CAPECOAST, TAKORADI, HO) }\end{array}$} & \multicolumn{3}{|c|}{$\begin{array}{l}\text { SOUTH WESTERN-EQUATORIAL } \\
\text { (AXIM) }\end{array}$} \\
\hline & \multicolumn{3}{|c|}{$1,689 \cdot$ BUILDINGS SURVEYED } & \multicolumn{3}{|c|}{ 545-BUILDINGS SURVEYED } & \multicolumn{3}{|c|}{ 3,541·BUILDINGS SURVEYED } & \multicolumn{3}{|c|}{ 56-EUILDNGS. SURVEYED } \\
\hline & $\begin{array}{l}\text { RISING } \\
\text { DAMPNES } \\
\text { S }\end{array}$ & $\begin{array}{l}\text { CONDENS } \\
\text { ATION }\end{array}$ & $\begin{array}{l}\text { WATER: } \\
\text { PENETRA } \\
\text { TION }\end{array}$ & $\begin{array}{l}\text { RISING } \\
\text { DAMPNES } \\
\text { S }\end{array}$ & $\begin{array}{l}\text { CONDENS } \\
\text { ATION }\end{array}$ & $\begin{array}{l}\text { WATER } \\
\text { PENETRA } \\
\text { TION }\end{array}$ & $\begin{array}{l}\text { RISING } \\
\text { DAMPNES } \\
\text { S }\end{array}$ & $\begin{array}{l}\text { CONDENS } \\
\text { ATION }\end{array}$ & $\begin{array}{l}\text { WATER } \\
\text { PENETRA } \\
\text { TION }\end{array}$ & $\begin{array}{l}\text { RISING } \\
\text { DAMPNES } \\
\text { S }\end{array}$ & $\begin{array}{l}\text { CONDENS } \\
\text { ATION }\end{array}$ & $\begin{array}{l}\text { WATER } \\
\text { PENETRA } \\
\text { TION }\end{array}$ \\
\hline $\begin{array}{l}\text { Water } \\
\text { droplets free } \\
\text { flowing water } \\
\text { on surface }\end{array}$ & 0 & $0+$ & 50 & 0 & 0 & 30 & Oe & 0 & 100 & 0 & 0 & 10 \\
\hline $\begin{array}{l}\text { Hygroscopic } \\
\text { salts }\end{array}$ & 180 & $0+$ & 0 & 55 & 0 & 0 & 2,000 & 0 & 00 & 20 & 0 & 0 \\
\hline $\begin{array}{l}\text { Moisture in } \\
\text { skirting }\end{array}$ & 90 & $0+$ & 0 & 20 & 0 & 0 & 150 & 0 & 0 & 4 & 0 & 0 \\
\hline $\begin{array}{l}\text { Moisture above } \\
1.5 \mathrm{~m}\end{array}$ & 0 & 0 & 200 & 0 & 0 & 75 & 0 & 0 & 100 & 0 & 0 & 10 \\
\hline $\begin{array}{l}\text { Dampness } \\
\text { below } 1.5 \mathrm{~m} \text { in } \\
\text { horizontal band }\end{array}$ & 1,000 & $0+$ & 0 & 200 & 0 & 0 & 1,000 & 0 & 0 & 10 & 0 & 0 \\
\hline $\begin{array}{l}\text { Mold on walls } \\
\text { about } 1 \mathrm{~m} \text { ' high }\end{array}$ & 100 & 0 & 0 & 100 & 00 & 0 & 116 & 0 & 0 & 10 & 0 & 0 \\
\hline $\begin{array}{l}\text { Mold on } \\
\text { ceilings and top } \\
\text { of walls }\end{array}$ & 00 & 69 & 0 & 0 & 65 & 0 & 00 & 105 & 00 & 00 & 20 & 0 \\
\hline $\begin{array}{l}\text { TOTAL NO. } \\
\text { OF- } \\
\text { BUILDNGS }\end{array}$ & 1,370 & 69 & 250 & 375 & 65 & 105 & 3,266 & 75 & 200 & 26 & 10 & 20 \\
\hline RANKS & $1 S T$ & $3 R D$ & $2 N D$ & $1 S T$ & $3 R D$ & $2 N D$ & $1 S T$ & $3 R D$ & $2 N D$ & $1 S T$ & $3 R D$ & $2 N D$ \\
\hline
\end{tabular}

The results show that $81 \%$ of buildings (1,370 buildings) in the Wet Semi Equatorial climatic zone were identified with symptoms such as 'hygroscopic salts', 'moisture in skirtings', 'dampness below $1.5 \mathrm{~m}$ in horizontal band' and 'mold growth on walls about $1 \mathrm{~m}$ high'. These are all symptoms highly associated with rising dampness (Hetreed, 2008; Burkinshaw \& Parrett, 2004; Trotman et al., 2004; Mbachu, 1999). The results also show that $15 \%$ of buildings ( 250 buildings) in this climatic zone were identified with symptoms such as 'water droplets or free flowing water on surfaces' and 'moisture above $1.5 \mathrm{~m}$ ', symptoms closely identified with water penetration (Burns, 2010; SEL, 2007). The results further show that $4 \%$ of buildings (69 buildings) in this climatic zone were identified with 'mold on ceilings and top of walls', a symptom associated with condensation (Burns, 2010; SEL, 2007).

In the Tropical Continental climatic zone, $69 \%$ of buildings (375 buildings) were identified with symptoms highly associated with rising damp such as 'hygroscopic salts', 'moisture in skirtings', 'dampness below 1.5m in horizontal band' and 'mold growth on walls about 1m high' (Hetreed, 2008; Burkinshaw \& Parrett, 2004; Trotman et al., 2004; Mbachu, 1999). Nineteen percent of the buildings (19\%) (105 buildings) located in this 
climatic zone were also identified with symptoms associated with water penetration such as 'water droplets or free flowing water on surfaces' and 'moisture above $1.5 \mathrm{~m}$ '. Furthermore, $12 \%$ of the buildings ( 65 buildings) were identified with 'mold on ceilings and top of walls' which is a symptom associated with surface condensation (Burns, 2010; SEL, 2007).

The survey in the Dry Equatorial climatic zone shows that symptoms such as 'hygroscopic salts', 'moisture in skirtings', 'dampness below $1.5 \mathrm{~m}$ in horizontal band' and 'mould growth on walls about $1 \mathrm{~m}$ high' were identified with $92 \%$ of the buildings (3,266 buildings). 'Water droplets or free flowing water on surfaces' and 'moisture above $1.5 \mathrm{~m}$ ', were identified with $6 \%$ of the buildings (200 buildings) and 'moulds on ceilings and top of walls' was identified with $2 \%$ of the buildings ( 75 buildings) in this climatic zone.

In the South Western Equatorial climatic zone, $46 \%$ of the buildings were identified with the symptoms of 'hygroscopic salts', 'moisture in skirtings', 'dampness below $1.5 \mathrm{~m}$ in horizontal band' and 'mould growth on walls about $1 \mathrm{~m}$ high'. Thirty six percent (36\%) of the buildings in this climatic zone were identified with 'water droplets or free flowing water on surfaces' and 'moisture above $1.5 \mathrm{~m}$ '. Mold on ceilings and top of walls were identified with $18 \%$ of the buildings in this climatic zone.

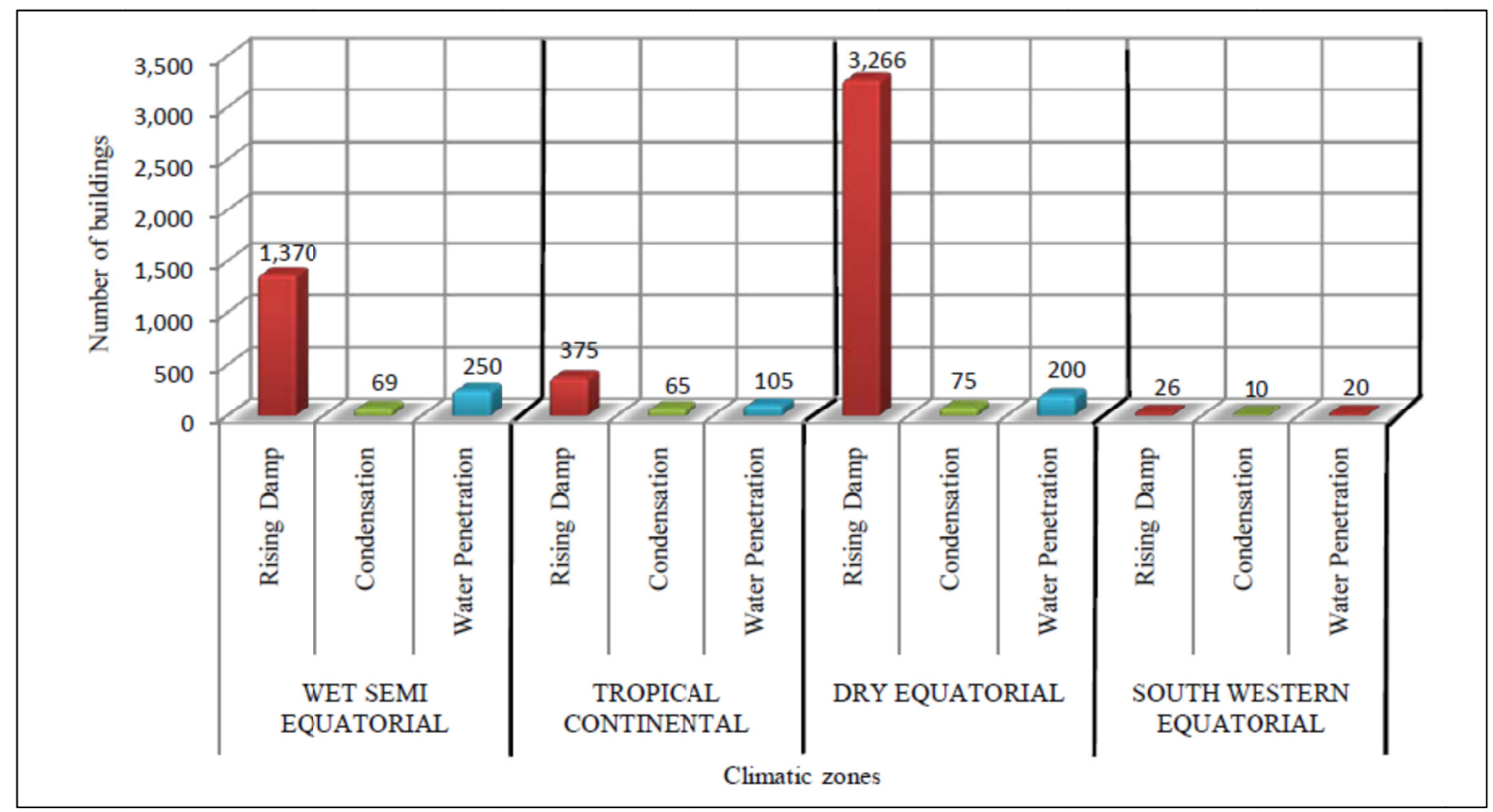

Figure 2. Number of buildings identified with rising dampness, condensation and water penetration in the four climatic zones

Figure 2 provides a summary of the most dominant types of dampness in the walls of buildings in the four climatic zones of Ghana. Figure 2 depicts that the most dominant type of dampness in walls of buildings in the four climatic zones is most probably rising dampness. This is because majority of buildings surveyed in the four climatic zones exhibited symptoms associated with rising dampness. Thus, 1,370 out of 1,689 buildings in the WSE climatic zone, 375 out of 545 buildings in the TC climatic zone, 3,266 out of 3,541 buildings in the DE climatic zone and 26 out of 56 buildings in the SWE climatic zone all exhibited symptoms associated with rising dampness.

\section{Conclusions}

This study sought to identify the most severe symptoms and also to identify the lead source of dampness in walls of residential buildings in the four climatic zones in Ghana. The results showed that the most dominant type of dampness in the walls of buildings is rising dampness and it is usually associated with symptoms such as hygroscopic salts, moist timber skirting, damp base of walls, etc. As a recommendation for further study, the authors suggest that a more detailed laboratory diagnosis be conducted of the problem of rising dampness in the masonry walls of residential buildings to aid in the recommendation of appropriate treatment mechanisms to address the problem. 


\section{References}

Abass, K. (2009). A regional geography of Ghana for senior high schools and undergraduates. Pictis Publications, Accra.

Ahmad, A. G., \& Abdul Rahman, H. F. (2010). Treatment of Salt Attack and Rising Damp in Heritage Buildings in Penang, Malaysia. Journal of Construction in Developing Countries, 15(1), 93-112.

Asamoah, A. S., Forson, A. G., \& Boakye, D. A. (2012). A review of epidemiological studies of asthma in Ghana. Ghana Medical Journal, 46(2), 23-28.

Australian Building Codes Board, ABCB. (2011). Condensation in Buildings: Information Handbook.

Bank of Ghana. (2007). The Housing Market in Ghana. Retrieved from www.bog.gov.gh/index.php?...housing-market-in-ghana

Beall, C. (2000). Water penetration in building envelopes. Retrieved from http://www.rci-online.org/interface/2000-10-beall.pdf

Briffett, C. (1994). Building Maintenance Technology in Tropical Climates-Investigating dampness problem in buildings, Singapore. Singapore University Press.

Burkinshaw, R., \& Parrett, M. (2004). Diagnosing damp. Coventry: RICS BOOK.

Burns, G. (2010). What is rising damp? Burns Property care Services. Retrieved December 2, 2013, from Burnspropertycare.com

Carillion, S. (2001). Defects in Buildings: Symptoms, investigations, diagnosis and cure. United Kingdom, The Stationary Office.

Chalmers University Library (n.d). Sustainability of the Swedish built environment towards climate change. Hygrothermal effects and design criteria for buildings with respect to future climate scenario. Retrieved August 9, 2009 from http//www.chalmers.se/___/building

Cukierski, G. (1999). Moisture condensation at the windows. Housing Fact Sheets. Cornell Cooperative Extension.

Curtis, R. (2007). Damp Causes and Solution.Published by Technical Conservation, Research and Education Group. Historic Scotland, Longmore House, Salisbury Place, Edinburgh EH 91 SH. Coral-ghana.com. Open House. A Coral Paint Publication, Issue 2.

Ghana Statistical Service. (2005). Popolation and Housing Census, 2000. Retrieved from www.statsghana.gov.gh/docfiles/Ghana\%20in\%20Figures.pdf

Gunnbjornsdottir, M. I., Franklin, K. A., Norback, D., Bjornsson, E., Gislason, D., Lindberg, E., ... Janson, C. (2006). Prevalence of respiratory symptoms in relation to indoor dampness: The Rhine Study. Thorax, 61(3), 221-225. http://dx.doi.org/10.1136/thx.2005.057430

Halim, A. A., \& Halim, A. Z. (2010). An analysis of Dampness Study on Heritage Buildings: A Case Study Ipoh Old Post Office Building and Suluh Budiman Building, UPSI, Perak, Malaysia. Journal of Sustainable Development, 3(4), 171-182.

Halim, A. A., Harun, S. N., \& Hamid, Y. (2012). Diagnosis of dampness in conservation of historic buildings. Journal Design Built, 5.

Hetreed, J. (2008). The damp House: A Guide to the causes and Treatment of Dampness.

Hollis, M. (2000). Surveying Building, Coventry, RB-RICS Books.

Idrus, A., Sodangi, M., \& HaqHusin, M. (2011). Prioritizing project performance criteria within client perspective. Research Journal of Applied Sciences, Engineering and Technology, 3(10), 1142-1151.

Karoglou, M., Moropoulou, A., Krokida, M. K., \& Maroulis, Z. B. (2007). A powerful simulator for moisture transfer in buildings. Building and Environment, $902-912$. http://dx.doi.org/10.1016/j.buildenv.2005.10.008

Mbachu, J. I. C. (1999). Dampness in Residential Building Walls: A case study of Angwan Rimi Ward of Jos Metropolis. Journal of Environmental Science, 3(1), 80-84.

Mudarri, D., \& Fisk, W. J. (2007). Public health and economic impact of dampness and mold. Indoor Air, 17(3), 226-235. http://dx.doi.org/10.1111/j.1600-0668.2007.00474.x 
Nicol, S. (2006). The relationship between housing conditions and health-some findings from the WHO LARES survey of eight European cities. In proceedings: ENHR Conference "Housing in an expanding Europe", theory, policy, participation and implementation, Ljubljana, Slovenia, 2-5 July, 2006.

NSWHO. (2005). Rising Damp. The Maintenance Series, ISBN 187641575 4. Retrieved September 3, 2012 , from www.heritage.nsw.gov.au/docs/maintenance 2-1_risingdamp.pdf

Riley, M., \& Cotgrave, A. (2005). Dampness in Buildings. Division of Sustainable Development. Retrieved from http://folders.nottingham.edu.cn

Ryan, V. (2002). Condensation in dwellings. Journal of Environmental Health Research, 1(1).

Safeguard Europe Limited (SEL). (2007). Rising damp and its control. A guide to identifying the various forms of dampness encountered in buildings and control of rising damp through remedial action. A Publication by Safeguard Europe Ltd.

South Northamptonshire Council, SNC. (2012). Damp in traditional buildings: Causes and solutions. Conservation Advice Note No. 6. Retrieved from www.southnorthants.gov.uk/Advice_note 6_damp.pdf

Trotman, P., Sanders, C., \& Harrison, H. (2004). Understanding Dampness. BRE Bookshop.

Wheeler, S., \& Critchley, R. (1998). Condensation dampness. Chartered Institute of Environmental Health Practice Notes.

World Health Organisation (WHO). (2009). Guidelines for indoor air quality: Dampness and Mould.

Yamane, T. (1967). Statistics, An introductory analysis (2nd ed.). New York: Harper and Row.

Young, D. (2008). Salt attack and rising damp. A guide to salt damp in historic and older buildings. Red Rover Text Print: ISBN: 978-0-9805126-4-9.

\section{Copyrights}

Copyright for this article is retained by the author(s), with first publication rights granted to the journal.

This is an open-access article distributed under the terms and conditions of the Creative Commons Attribution license (http://creativecommons.org/licenses/by/3.0/). 